Western University Scholarship@Western

Aboriginal Policy Research Consortium International (APRCi)

1999

\title{
Visiting Aboriginal Australia
}

Stephen Muecke

Follow this and additional works at: https://ir.lib.uwo.ca/aprci

Part of the Social and Cultural Anthropology Commons

Citation of this paper:

Muecke, Stephen, "Visiting Aboriginal Australia" (1999). Aboriginal Policy Research Consortium International (APRCi). 316. https://ir.lib.uwo.ca/aprci/316 
This article was downloaded by: [University of Western Ontario]

On: 07 December 2012, At: 07: 38

Publisher: Routledge

Informa Ltd Registered in England and Wales Registered Number:

1072954 Registered office: Mortimer House, 37-41 Mortimer Street, London W1T 3J H, UK

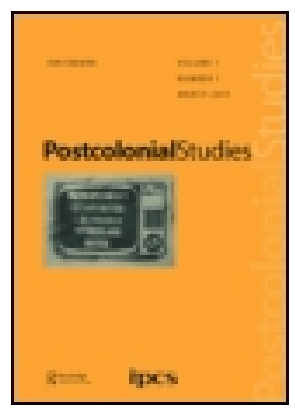

\section{Postcolonial Studies}

Publication details, including instructions for authors and subscription information: http:// www.tandfonline.com/loi/ cpcs20

\section{Visiting Aboriginal Australia}

Stephen Muecke

Version of record first published: 19 Aug 2010.

To cite this article: Stephen Muecke (1999): Visiting Aboriginal Australia, Postcolonial Studies, 2:1, 49-54

To link to this article: http:// dx.doi.org/ 10.1080/13688799989887

\section{PLEASE SCROLL DOWN FOR ARTICLE}

Full terms and conditions of use: http://www.tandfonline.com/page/ terms-and-conditions

This article may be used for research, teaching, and private study purposes. Any substantial or systematic reproduction, redistribution, reselling, loan, sub-licensing, systematic supply, or distribution in any form to anyone is expressly forbidden.

The publisher does not give any warranty express or implied or make any representation that the contents will be complete or accurate or up to date. The accuracy of any instructions, formulae, and drug doses should be independently verified with primary sources. The publisher shall not be liable for any loss, actions, claims, proceedings, demand, or costs or damages whatsoever or howsoever caused arising directly or indirectly in connection with or arising out of the use of this material. 


\section{Visiting Aboriginal Australia}

\section{STEPHEN MUECKE}

... the content of an idea matters a little less than the way it is put into practice. ${ }^{1}$

Not enough imagination has gone into the different modalities of situatedness-indisplacement. ${ }^{2}$

\section{In the bath}

When I arrived in Perth, in 1974, for my first job teaching linguistics in the Anthropology Department at the University of Western Australia, I was advised to consult with 'Prof' before heading north to do 'field-work'. A venerable and benevolent figure in his study, puffing his pipe, he ordered tea and then issued me with two prohibitions to equip me in the field. 'Don't have anything to do with Aboriginal women,' he said, 'or Aboriginal politics.' I was embarrassed, for only the other night I had been in Gloria's bath. When I had moved into the Everett St. flats, my hot water was out of action, so Gloria, immediate neighbour across the hall, acquaintance and an Aboriginal student at the uni, had invited me to use her tub. She was amused, popping her head around the door as I enjoyed the bubble bath, offering a towel, and then a bit later, 'Would you like a Martini?'

Now of course I could understand that this was not quite the same thing as a professional relationship 'in the field' with real 'informants'. And when later I was equipping myself materially for the trip in the Anthropology storerooms and found blocks of chewing tobacco along with tents and camp stretchers, I knew that I was dealing with a different category of people, with whom 'professional relationship' would not mean friendship, however intimate, but rather a permanent subaltern status for which chewing tobacco was an emblem in a primitive economy. Let us not be mistaken; there have often been cases of sex getting in the way of work; and a previous researcher in the department had had quite a complicated life up in Broome. I later looked up his thesis searching, I confess, more for personal and domestic detail than information about Broome's social structure in the 1970s.

A sea-change was happening in the humanities, I had intuitions born of my time in France in 1968; paradigms were groaning and shifting. The intellectual distance marked by the knowing subject and the object of knowledge was about to be broached from multiple directions: indigenous knowledges were starting to assume overt agency in the determinations of research agendas; the subjectivity

Stephen Muecke is Professor of Cultural Studies at the University of Technology, Sydney. His latest books are No Road (bitumen all the way) Fremantle Arts Centre Press, 1997, and a translation of José Gilís Metamorphoses of the Body, Minnesota University Press, 1998. He is co-editor (with Meaghan Morris) of The UTS Review: cultural studies and new writing. 
or identity of the academic researcher was challenged and was leading to self-reflexivity, narrativisation and negotiation of one's speaking position: real friendships were beginning to count more; urgent Aboriginal political agendas were installing themselves in the quid pro quo of fieldwork relations, so that the exchange of knowledge for chewing tobacco was exposed as laughably trivial. Anthropologically inspired protectionist and preservationist strategies were now less relevant as key Aboriginal professionals and activists, like Gloria Brennan, were emerging and asserting self-determination.

My response to these intuitions and events was at first formalist, and later somewhat poetic. Linguistic formalism had, like anthropological structuralism, used form as a pretext for democratisation. It taught that any language was as complex as any other, that none was more advanced, that each was evidence of sophisticated humanity. So in the mid-1970s my work on Aboriginal English had to work against entrenched assumptions about the 'worthlessness' of Aboriginal English, a pidgin language, on the way to becoming a creole. These assumptions were present among, for instance, primary school teachers in the Kimberley, who had never been taught about the (multi-)linguistic background of Aboriginal children. To them the 'funny talk' of such children would therefore tend to be understood as part and parcel of racial inadequacy in a social Darwinist framework. Language was in place as one of the barriers that sustained racial segregation in this frontier society. I realised that I was observing a totalitarian situation: a kid speaking Aboriginal English could not escape, for instance, by walking into town and getting a job like white people.

The problem posed by such a totalitarian situation is one of understanding. How can one come to terms with the enormity of it all, the total subjugation of a race? One can yearn, now, to have been a Henry Reynolds avant la lettre, and to have seen this situation as thrown up by historical forces. But my understanding was both enabled and restricted in the first instance by the objectivity offered by formalism, as if by putting this language on an even footing with that language would demonstrate, via description, their equality, and by extension, the equality of their speakers. How limited this understanding was, and how arrogantly it assumed the power of science to change attitudes by decree!

\section{In the middle of the story}

What was needed was a more complex story. But who was to tell it, and how?

I had set myself the task of collecting stories in Aboriginal English which, for the purposes of doctoral study, I would analyse according to a narratology combining systemic-functional clause level grammar with a broader grammar of story 'events' and 'participants' arranged in sequences. This all went very well, but at the end of the process I came to understand that there is another stratum of material making up a story that cuts across formal categories. This stratum, composed of cultural material, is best thought of as 'statements' (defined either as énoncés, in the Foucauldian sense, or in a more mundane sense akin to 'making a statement' in a police station, as if your freedom depends on what you say). The idea of a story making a statement implies contingency, singularity and rarity, because the story is responding to the real experience of the narrator, and 
is designed to make that experience relevant to the listener in the circumstances of telling. The story has the 'point' of relating what 'they were doing then' to what 'we are doing now', not with a locked-in determinism, but with the 'room for manoeuvre' that encourages the play of interpretation in the enchanted mind of the listener. ${ }^{3}$

So I transcribed the wonderful stories of Paddy Roe with a technique imitative of the spoken word, reproducing rhythms, emphasis and context:

So we gettin' ready to go you know we started off 'bout-

from here to the building-

old woman, my old woman get sick-

'Oh,' he tell me, 'I get sick little bit'-

(Soft) 'Oh, what wrong?' I say-

'I dunno,' he say, 'must be that honey, waladja'-(Benterrak, p 130 $)^{4}$

Paddy Roe's story of the onset of his wife's first pregnancy is told in a very specific cultural and political context. Cultural because it is about a 'conception dreaming'; the daughter will be born 'as a stingray'; and political because this dreaming will attempt to establish the daughter's custodianship of that country in the context of actual Broome land-rights claims and counter-claims. It is told with sensitivity (the softening of the voice expressive of husbandly concern) and the phrase 'from here to the building - ' relates our storytelling situation to the spatiality of the events of some 50 years before. The listener's attention is thus solicited; the modulation of speech and pause, volume, repetition and reference weaves an enchantment.

I was recently accused in this of 'staging an Aboriginal side-show for [my] own benefit' because I juxtaposed my texts to Paddy Roe's in a book with three authors. ${ }^{5}$ But I think this 'giving voice' in Australian literature to an Aboriginal man was a response to the traditional anthropological strategies of simply taking knowledge without attribution to any individual; to practices of paraphrase and radical summary, to practices of handing out a few sticks of chewing tobacco in exchange for many hours of "informants" work. My work with Paddy Roe was the first time to my knowledge that an Aboriginal research associate had been attributed joint authorship in an academic work, and given an equal share of the royalties. ${ }^{6}$ My reading of Foucault had also given me a fascination with the rarity and historical contingency of possible statements. I stated early in the book that:

Paddy Roe's texts can be read independently (and must be read) as paradoxically included in the book, and thus incorporated in the broader culture, but extending before and beyond the covers (already crossing the country before the book was thought of), one word after the other like footsteps: lively spoken words. These are the words which most clearly and consistently tell of the country. They are set in the context of a Babel of other voices - writings - from the past and present which clamour around and are, in contrast, quite ephemeral. Restricted to particular historical periods, they are the other discourses on the country. There will be more to come, following in Paddy Roe's footsteps, or ignoring them. But one ignores the local guide at one's own peril, for he is telling us how to survive in this country, and survival depends not just on the right sort of physical treatment of the country, but also on what one says about it, writes about it, and the images one makes of it. $^{7}$ 
Reading the Country was subtitled Introduction to Nomadology. The 'nomadological' principle, borrowed both from Deleuze and Guattari and the Kimberley people with whom I was talking, was one of deferred authority-'ask that oldfella' was what one would often hear. The relation between my text and Paddy Roe's was not hermeneutic, there was no pre-given theoretical relation and the book both problematised the status of 'writing' and signalled with the author's name his legal rights to what he was saying. If this was an instance of a kind of postmodernism, then it was designed to be of an ethically driven sort.

In it I spoke of 'nomadic writing' as a metaphor; it was about the deferral of authority and the metonymy of desire; I was at pains to point out that I did not think any society is actually 'nomadic'. So, in defending the book Paddy Roe entrusted me to create with him, I can't help thinking of him, now, in Broome, in his frail old age. Whatever the ambiguities and injustices of 'speaking for' him are, I am sure that the politics of cultural survival, that is survival into historical recognition, involves a bit of a struggle. This struggle is not between, say, cultural studies and anthropology, arguing which theory is best for indigenous peoples. It is not a question of getting the theory right (millions of indigenous people are no doubt indifferent). It is a question of reserving a place at the negotiating table and then listening. Reading the Country created such a place in the domain of Australian literature for Paddy Roe, and the book is an archive of his words, maps and images more than it is an application of any sort of theory.

This kind of writing, in the encounter with other cultures, was one that also left spaces, sometimes literally in the text as indications of the unsaid or the not-yet-understood. It is consonant with what Kathleen Stewart in her excellent work of 'new ethnography', calls 'a space on the side of the road'. ${ }^{8}$ This, both for the West Virginians and the writer, is a narrative space in which culture fills out its potential and imagination, materialised as sites of cultural singularity and local knowledge, yet in movement, for the road is always a medium for getting along. It is the 'room for manoeuvre' or the always-another-chair-at-the-table principle that enables negotiation in and through storytelling.

\section{Training the imagination}

Hannah Arendt has a useful metaphor for training the philosophical imagination: 'thinking without a banister'. 'Banisters are virtual supports, they guide one's movement up the stairs even though one is perfectly capable of mounting the stairs without them. Pulling the banisters out of one's thinking is a way of removing ingrained thought patterns, which impede not only the ability to see things afresh, but to experience them afresh and tell new stories about them. In my work in Aboriginal Australia, I have no recollection of any banisters: their literal absence makes me want to translate the metaphor, and there the notion of ascent or transcendence was not a metaphor for enlightenment either. More often, on the road, the road itself was a kind of banister, for in Aboriginal Australia there are tracks. Roads are for transport and progress, tracks represent traditional movement of people criss-crossing the country. To know the tracks and the sites they connect remains special local knowledge. 
The researcher, someone like myself going around asking about stories, is a visitor in Aboriginal country, and visiting protocols apply. We have been trained from an early age to be on our best behaviour when visiting. We wait patiently and listen until we are invited to do something, and yet at the same time we are alert - not for danger because as visitors our hosts have offered us sanctuary and they are conscious of their responsibility to look after us-for the cultural gifts that we will take away in the form of stories.

Visitors are traders in stories, and visiting is a process that enhances the imagination (story-like in its own movement of anticipation, encounter, exchange, return). Seeing oneself as a visitor on the lookout for stories is a quite different thing from being a researcher equipped with theories. As Lisa Disch, commentator on Arendt says:

A well crafted story shares with the most elegant theories the ability to bring to light a version of the world that so transforms the way people see that it seems never to have been otherwise. ${ }^{10}$

The experience of being a visitor, or 'training the imagination to go visiting', is one of imagining oneself in the place of the other while remaining oneself. ${ }^{11}$ Both Arendt and her commentator allow, I think, for a plurality of selves as well as a plurality of others, for the most important thing is to be in a position to be able to produce political judgements which work rhetorically. So since 'the first concern of political judgement is not to safeguard the integrity of a single actor but to articulate a principle that others would be inspired to take up', ${ }^{12}$ this would mean that political judgement will not be based in timeless and universal abstract arguments, but would assure their contingency by showing how these judgements grew out of particular experiences. A story, says Disch 'can represent a dilemma as contingent and unprecedented and position its audience to think from within that dilemma'. ${ }^{13}$ The weaving of the specific with the general is a familiar rhetorical strategy, and a way of making a convincing argument while telling a good story at the same time.

In the specific encounter between academic-non-academic discourses, where writers decide that 'this goes with that' for whatever reason, then it would seem reasonable to tell stories from the academic side of experience that established the conditions under which a certain sort of academic knowledge was deemed useful in non-academic settings and vice-versa: how experiences 'out there' came to reform the discipline. Visiting then is clearly a two-way road:

Visiting involves constructing stories of an event from each of the plurality of objectives that might have an interest in telling it and imaging how I would respond as a character in a story very different from my own. It is a kind of representation that arrives at the general through the particular ... Visiting should be distinguished on the one hand from the abstract generality of Kant's account of taste, which is a kind of tourism that preserves a spectatorial distance, and from the immediacy of empathy on the other, which is a kind of assimilationism. In order to tell yourself the story of an event from an unfamiliar standpoint, you have to position yourself there as yourself. ${ }^{14}$

Speaking as myself, and as an Australian, there is something of a dilemma in visiting others within my own country. Aboriginal people have been playing host 
to a lot of visitors over the years, going backwards and forwards with changing stories about what they experience in Aboriginal country. The paradox of 'visiting Aboriginal Australia' concerns the unresolved political question of 'them' and 'us'. At what level are we the same people within a nation? Could we embrace each other in a symbolic elimination of difference in some nationalist ceremony? And continue the visiting process at a more mundane and cultural level, even next door to take a bath, so that narratives of difference will be the vehicles for greater understanding?

\section{Notes}

${ }^{1}$ M Serres, The Troubadour of Knowledge, Ann Arbor, University Michigan Press, 1997, p 122.

2 B Robbins, 'Comparative Cosmopolitanisms', in Peng Cheah and Bruce Robbins, eds., Cosmopolitics: Thinking and Feeling Beyond the Nation, Minneapolis, University of Minnesota Press, 1998, pp 246-264, p 250.

3 R Chambers, Room for Maneuver: Reading the Oppositional in Narrative, Chicago: Chicago University Press, 1991.

${ }^{4}$ In this kind of Aboriginal English the pronoun is not marked for gender.

5 G Huggan, '(Post) colonialism, anthropology, mimesis', Cultural Critique, No 38, 1997, pp 91-106, p 99

${ }^{6}$ Anthropologists had worked with Paddy Roe since the $1950 \mathrm{~s}$, but there was nothing under his name in the library of the Institute of Aboriginal Studies when I began to work with him in 1977.

${ }^{7} \mathrm{~K}$ Benterrak, S Muecke and $\mathrm{P}$ Roe, Reading the Country: Introduction to Nomadology. Liverpool, University of Liverpool Press, 1996 [1984], pp 27-28

${ }^{8} \mathrm{~K}$ Stewart. A Space on the Side of the Road: Cultural Poetics in an 'Other' America. Princeton, Princeton University Press, 1996.

${ }^{9}$ L J Disch, Hannah Arendt and the Limits of Philosophy, Ithaca, Cornell University Press, 1994, pp $143-146$. I am grateful to Michael Jackson for pointing out this reference.

${ }^{10}$ L J Disch, Hannah Arendt, p 106.

11 L J Disch, Hannah Arendt, pp 146-164.

${ }^{12}$ L J Disch, Hannah Arendt, p 152.

13 L J Disch, Hannah Arendt, p 110.

${ }^{14}$ L J Disch, Hannah Arendt, p 158. 